\title{
The impact of e-portfolio on foreign language writing skills"
}

\section{Derya ERICE**}

\author{
Abdullah ERTAŞ *** $^{*}$
}

\begin{abstract}
This study explores the effect of e-portfolio use on developing the writing skills of English language learners who are at the pre-intermediate language proficiency level. The experiment group $(n=23)$, were asked to enroll in an online classroom to keep online portfolios whereas the control group $(n=24)$ kept paper portfolios. 'The Motivation Strategies for Learning Questionnaire' and Computer Attitude Questionnaire 'were used in addition to the 'Computer Literacy Survey' to collect data. This study provides insights into using portfolio through online writing practice compared with paper-based practice in terms of achievement. The results suggest that 1) The digital environment contributes to language writing skills. 2) Factors of previous computer experience and computer ownership influence computer attitudes. 3) E-portfolio can be integrated into foreign language teaching curricula.
\end{abstract}

Keywords: Foreign language teaching, portfolio, writing skills, computer assisted language learning.

\footnotetext{
* PhD dissertation, Gazi University, Faculty of Education, English Language Teaching Program, Ankara.

Assist. Prof. Dr., Abant İzzet Baysal University, Faculty of Education, English Language Teaching Program, E-mail: erice_d@ibu.edu.tr

Assist. Prof. Dr., Gazi University, Faculty of Education, English Language Teaching Program, E-mail: aertas@gazi.edu.tr
} 


\section{ÖZET}

Amaç ve Önem: Çalışma çevrim içi değerlendirme aracı olarak elektronik portfolyonun yabancı dil öğrenen hazırlık sınıfı öğrencilerinin yabancı dilde yazma becerileri üzerindeki etkilerini araştırma amacını taşır. Aynı zamanda, Türkiye'de e-portfolyo ile ilgili yapılan çalışmaları inceleyerek yazma becerisi başta olmak üzere e-portfolyonun etkilerini çok yönlü irdelemesi açısından önemlidir.

Yöntem: Bilgisayar Okuryazarlığı Anketi ile çalışmaya katılan ögrenciler hakkında demografik bilgiler toplanmıştır. Deney ve kontrol grubu öğrencileri Öğrenme için Motivasyon Stratejileri (MSLQ) ve Bilgisayar Tutum Anketlerini (CAQ) tamamlamışlardır. Deney grubu kelime işlemcisi temelli Dokeos adlı çevrim içi ortamda elektronik portfolyo oluştururken kontrol grubu da dosya şeklinde yazılı portfolyo oluşturdular.

Bulgular: Ön ve son test sonuçlarına göre elektronik portfolyo kullanıcılarının dosya şeklinde portfolyo oluşturan öğrencilerden yazma becerileri açısından daha başarılı olduğu görülmüştür. Diğer taraftan, motivasyon açısından kontrol ve deney grubu açısından uygulama öncesinde bir fark gözlemlenmemiştir. Bilgisayar kaygısı, bilgisayardan keyif alma ve bilgisayara önem verme açısından elektronik portolyo kullanıcıları olumsuz bulgular ortaya koymuştur.

Tartısma ve Sonuçlar: Teknoloji kullanımı, ikinci dilde yazma becerisi ve değerlendirme boyutlarıyla bu çalışma elektronik portfolyonun dil eğitimi müfredatında yer alabileceğini öngörmektedir. Çalışmanın öğrencilere ek olarak öğretmenler, idareciler ve velilerin teknolojinin öğrenme aracı olarak kullanmasına ilişkin olumlu görüşler oluşmasına katkı sağlayacaktır. 


\section{Elektronik Portfolyonun Yabancı Dilde Yazma Becerileri Üzerindeki Etkisi*}

Derya ERICE ${ }^{* *}$

\author{
Abdullah ERTAŞ ${ }^{* * *}$
}

ÖZ. Bu çalışma elektronik(e-) portfolyonun orta alt yabancı dil seviyesindeki hazırlık sınıfi öğrencilerinin yazma becerileri üzerindeki etkisini araştırmaktır. Bir grup lisans öğrencisi çevrim içi sınıf ortamında elektronik portfolyo oluştururken, diğer bir grup da yazılı dosya şeklinde portfolyo oluşturmuşlardır. "Öğrenme için Motivasyon Stratejileri Anketi" ve "Bilgisayar Tutum Anketi" ile "Bilgisayar Okuryazarlığı Anketi” aracılığıyla veri toplanmıştır. Çalışma ile teknoloji destekli yazma pratiği ile dosyada yazma pratiği karşılaştırmasıyla elektronik ortamın başarıya etkisi hakkında bilgi sunulmuştur. Çalışma sonuçlarına göre 1) Dijital ortam yabancı dil yazma becerilerine olumlu etki etmektedir. 2) Bilgisayar kullanım deneyimi ve bilgisayar sahibi olma bilgisayara karşı tutumu etkilemektedir. 3) Elektronik portfolyo yabancı dil öğretim müfredatında yer alabilir.

Anahtar Sözcükler: Yabancı dil eğitimi, portfolyo, yazma becerileri, bilgisayar destekli dil eğitimi.

\footnotetext{
* Doktora tezi, Gazi Üniversitesi, Eğitim Fakültesi, İngilizce Öğretmenliği Bölümü, Ankara. *** Yrd. Doç. Dr., Abant İzzet Baysal Üniversitesi, Eğitim Fakültesi, İngilizce Öğretmenliği Bölümü, E-posta: erice_d@ibu.edu.tr

*** Yrd. Doç. Dr., Gazi Üniversitesi, Eğitim Fakültesi, İngilizce Öğretmenliği Bölümü, Eposta: aertas@gazi.edu.tr
} 


\section{INTRODUCTION}

Along with the explosion of new technologies emerged the necessity for integration of technology into teaching practices in all fields. Technology, specifically, computers and the Internet provide language learners with many opportunities like communicating with native speakers in an authentic written and oral environment, accessing the most recent information instantly and doing research (Warschauer, 2007).

This study is limited to the electronic portfolio (e-portfolio) on that many studies (Al Kahtani, 1999; Bryant \& Timmins, 2002; Chang, Wu, \& Ku, 2004; O’Malley \& Valdez Pierce, 1996; Tierney, Carter, \& Desai, 1991) resulted in positive outcomes and its effect on the development of language skills. The language focus of this study is writing skills as it is the most preferred way of assessing student performance basically through written exams. Written exams as proof of achievement are easy to record and access, and concrete to be analyzed by teachers as well as parents (White, 1987). Hence, upon educators' realization of need for research with a focus on alternative assessment in an innovative and state-of-art manner, this study aims to contribute to filling the related literature gap in the Turkish context. Additionally, the principal theory base here is constructivism that intends to get learners actively involved in construction of meaning considering specifically process throughout the task (Williams \& Burden, 1997). Constructivism can be observed in this study while students are engaged in creating their own portfolios and take part in decision making as well as content selection processes.

The shift from product to process writing and changes in the assessment methods and strategies has had a profound effect on writing instruction. Firstly, new varieties of tasks and genres have emerged dramatically such as: (E-) journal writing, peer (online) conferencing, (e-) collaboration in small groups, (e-) brainstorming, outlining, free (e-) writing, multiple drafting and peer (e-) revision, writing for different (e-) audience, and class (e-) publication. Secondly, the writer has become more autonomous in that he feels more like the owner of the text than before. Thirdly, the role of teachers and students has shifted from teacher-centered to constructivist approach in which students learn by doing while teachers are more like facilitators rather than sole controllers (Warschauer, 2007).

\section{Portfolios in Language Classrooms}

Portfolio is defined as "a collection of items that reveal different aspects of an individual child's growth and development over time." (Shores \& 
Grace, 1998). Portfolios have been classified in many ways. Gülbahar and Köse (2006) grouped portfolios along with their functions as a 'learning portfolio' for professional development, an 'assessment portfolio' for performance assessment, and a 'working portfolio' for career building. Whereas Jenkins (1996) categorized portfolios as benchmark, collaborative portfolio and showcase from the most teacher-centered to the least, respectively. The benchmark portfolio is assessed using checklists and benchmarks set by the teacher as the sole provider of information and standards. The showcase portfolio is the most student-oriented one, centering on self-assessment by students engaged in setting goals, selecting and reflecting on their own work. Lastly, the collaborative portfolio finds a way in-between where the learner and the teacher meet to achieve the ultimate goal.

A wide variety of items can be found in portfolios like presentations, articles, animations, videos, sound files, graphs, charts, hyperlinks, concept maps, posters and any other type of work by the student (Gülbahar \& Köse, 2006). Tierney, Carter, and Desai (1991) listed the elements for readingwriting portfolio as projects, surveys, reports, favorite poems, songs, letters, comments, interesting thoughts to remember, examples of texts across the curriculum (reports, journals and literature logs), literature extensions (scripts for drama, visual arts, written forms, webs, charts). Other options are stated as videos, dialogues, hyperlinks to references, chat logs, simulations, graphics, sound files and other presentation media. This rich variety of options makes portfolio flexible and easy to adapt to different contexts.

\section{Technology in Language Teaching and Assessment: E-portfolio}

Computer Mediated Communication (CMC) presents a number of advantages for enhancing language learning; interactive learning environment, collaborative writing in the second language classroom, and fostering student empowerment (Warschauer, Turbee \& Roberts, 1996), and in addition, emphasizes the role of social and affective factors in foreign language learning (Li, 2000). Several researchers (Aydın, 2006; van Waes, 2004) compared the nature of writing through computers and the one with the pen and paper mode favoring the former.

E-portfolio allows learners to practice both the computers and writing skills. Several studies (Al Kahtani, 1999; Avraamidou \& Zembal- Saul, 2002; Woodward \& Nanlohy, 2004) can be listed to name the specifics and advantages of e-portfolios. To start with, Al Kahtani (1999) compared electronic to the paper portfolio, and concluded that e-portfolio is less difficult to implement and less time consuming while it provides better and 
easier access to content and information, and helps teacher in planning lessons in line with the progress observed in the online portfolio process. Furthermore, Avraamidou and Zembal- Saul (2002) favored using eportfolios that support (self) reflection, more control over the learning procedure and allow flexibility for both the learner and the teacher. It is observed that the idea of online publishing of one's work that would be visible to all Internet users leads to an increase in the user motivation and self-confidence. Finally, the participants of the research conducted by Woodward and Nanlohy (2004) successfully performed a reflective approach through their portfolios by exchanging feedback between their peers and the teacher, also by self-assessing via following the set standards.

As for the drawbacks of e-portfolio use, the spell check and auto correction options could be listed that allow students to care less about issues of spelling, subject verb agreement, verb confusion and so forth as either they are automatically corrected or correct forms are provided by signaling the mistakes. Secondly, students might fear losing the uploaded and saved documents in the online environment. Lastly, inexperience in using the programs and the fear for possible hard/software problems could cause anxiety and reluctance (Tezci \& Dikici, 2006). Sanalan and Altun (2002) suggested that initially computer literacy skills should be built and then feedback should be provided constantly to keep track of the progression to get the most out of such practices. Finally, Jenkins (1996) described how teachers who were accustomed to the product oriented, and teacher-centered assessment types react negatively to the portfolio use especially at the beginning. It is proposed that once teachers can change their perspective on how to deliver and integrate new approaches, the outcomes are likely to be much positive such as in the integration and adaptation of technology into classes. In a recent study carried out with in-service teachers, Stansberry and Kymes (2007) asked teachers to create e-portfolios for four semesters and then checked the teacher willingness in using e-portfolios for their own teaching. They found that contrary to students' uneasiness at the portfolio, several teachers favored the process stating that technology use could turn the classroom into a dynamic place.

This study seeks to find the effect of e-portfolio on the writing skills of English language learners with a focus on technology integration, alternative assessment and writing skills. It has been observed that advance in technology and search for alternative ways of assessing writing skills have been playing an important role in language classrooms. 


\section{METHOD}

This study was carried out during the fall semester of 2007-2008 academic year at Abant İzzet Baysal University (AIBU) School of Basic English with the English language learners at the pre-intermediate language level. Forty-seven students participated in the study, 23 of them were experimental and 24 the control group. For the whole semester the experimental group developed an online portfolio working on a word processing file in an online classroom environment and the control group kept paper portfolios for the whole semester. Two questionnaires 'Computer Attitude Questionnaire' and 'Motivated Strategies for Learning Questionnaire` and a computer literacy survey were administered.

The Writing Skills course at the School of Basic English required a coursepack of tasks and activities prepared by the instructors referring to the Writing Tasks book written and published by the Middle East Technical University (METU) and therefore the tasks for the portfolio project was selected from this reference book; in addition Active Skills for Reading (Thompson Publishing); Reader at Work (METU Publishing) and More to Read (METU Publishing) were used to select the tasks for the test. The portfolio process of 10 weeks included assigning tasks, giving and managing the feedback while guiding the learners. Questionnaire data were analyzed using SPSS (Statistical Package for the Social Sciences) software program. The portfolios (online and paper) were analyzed using checklists designed for peers and teachers/ raters. Furthermore, a pre and post task-based writing test were administered to see the development in their writing skills at the paragraph level and thereby to observe the effect of the treatment.

The research questions posed in this study are the following: Is there a significant difference between the e-portfolio experimental group and the paper portfolio control group:

- in terms of attitude towards educational use of computers?

- anxiety towards educational use of computers?

- importance given to computers?

- enjoyment towards educational use of computers?

- writing skills development?

\section{Data Collection Instruments}

\section{Computer Attitude Questionnaire}

The Computer Attitude Questionnaire (CAQ v5.22) was originally developed by Knezek, Christensen and Miyashita in 1998. The original form has 80 items, 7 subscales and is a 5-point Likert type. It has been used to discover attitudes of teachers and students toward information technology and computer programs with the internal consistency reliability ranging from .80 to .87 , (Knezek et al., 1999; Soloway et al., 1999). The permission to use the questionnaire was granted through email in October 2007 from Gerald Knezek. 
In this study, only the first subscale of the questionnaire was used. The researcher analyzed the item content and excluded its five items. Negatively worded items are reversed when analyzing the data. The original questionnaire in English was first translated into Turkish by three language experts two are graduates from Translation and Interpretation department and then forms are re-translated to English to see the acceptability of the translation in terms of its meaning and form; the experts concluded that translated form is valid to a great extent.

\section{The Motivated Strategies for Learning Questionnaire}

The Motivated Strategies for Learning Questionnaire (MSLQ) was developed by Pintrich, Smith, Garcia and McKeachie (1991) with the theoretical basis of social-cognitive view of motivation and learning strategies. It has 81 items including motivation (31 items) and learning strategies (31 items) and student management of different sources (19 items) subscales. The negatively loaded items in the scales have been reversed before the adapted form of the questionnaire is finalized.

It was adapted into Turkish by Büyüköztürk, Akgün, Özkahveci and Demirel in 2004. After the adaptation the questionnaire had two subscales as the Motivation and the Learning Styles. Büyüköztürk et al. (2004) applied the questionnaire on a group of 852 students and conducted analysis of exploratory and confirmatory factor analysis, Cronbach Alpha correlation coefficients, corrected item-total correlations and t-tests and concluded that the first subscale would have six and the second have nine items. The Cronbach Alpha coefficients varied between 0.86 and 0.41 while corrected item total correlations ranged from 0.66 to 0.19 .

\section{Data Collection Environment}

Twenty-three students kept e-portfolios for 10 weeks starting with an orientation week where information about (e-) portfolio as an alternative assessment tool, the role of technology in assessment and writing skills were provided. During the orientation, each student created an account at Dokeos and practiced its features; the sample task was completed with the help of the teacher and the peers and a guideline was uploaded along with the list of peer-review list for feedback. One of the goals of this orientation session was to make them feel comfortable about using computers for learning purposes and to show how user-friendly the online environment is. First task was to write a paragraph introducing themselves along with their profile pictures. Therefore, what and how to upload files and pictures was demonstrated reminding the copyright and intellectual property rules. At the end, meeting time at the computer lab which is between 16.00 and 17.00 on Thursdays 
was announced. However, in order to eliminate the bias on research, each week paper portfolio group was also met to assign and announcing the task in class and to give feedback and answer questions of the students.

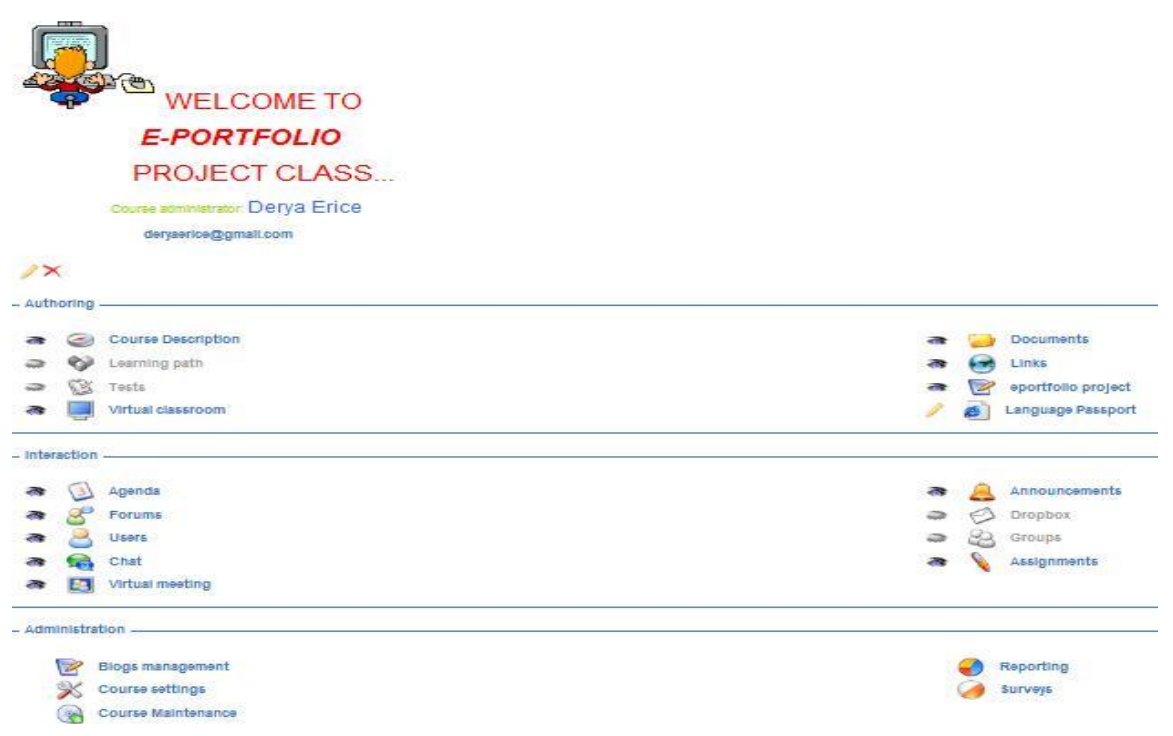

Figure 1. Interface for home page of the e-portfolio application

Dokeos, an open source e-learning and course management tool, was used to collect data (http://campus.dokeos.com/index.php) where it is possible to upload files for both teachers and students without any storage limit. In its most common use, students upload their assignments while teachers share files related to the course content such as assignments, announcements, videos or audio files. Dokeos offers opportunities to chat, to join forums, to conference for student-student, teacherstudent exchange and feedback (See Figure 1).

\section{FINDINGS}

\section{Computer Attitude Questionnaire}

Computer Attitude Questionnaire (CAQ) with 15-item was piloted on 60 preparatory class students at Abant Izzet Baysal University. It was assumed that the preparatory school students have had more or less the same level of foreign language proficiency and been through similar instruction. The data collected about the computer attitude were analyzed by SPSS program; the validity evaluated by factor analysis while Cronbach's alpha coefficient wss reported. In addition, principle component analysis was applied as a factoring technique.

The number of items per subscale is as following; 3 items on Computer Enjoyment, 5 on Importance and Anxiety with 7 items. The factor analysis of the 
scale statements verified these three dimensional structure. Five items with low loadings and those assigned to items of the same item have been excluded from the scale. The factor self-values, variances announced and scree-plot curve also indicated a three factor structure.

Table 1. Factor Analysis Results for $C A Q$

\begin{tabular}{|c|c|c|c|}
\hline \multirow{2}{*}{ Scale Items } & \multicolumn{3}{|c|}{ Components } \\
\hline & Anxiety & Importance & Enjoyment \\
\hline M1 & & & \\
\hline M2 & .74 & & \\
\hline M3 & .74 & & \\
\hline M4 & .69 & & \\
\hline M5 & .67 & & \\
\hline M6 & & .84 & \\
\hline M7 & & .79 & \\
\hline M8 & & .66 & \\
\hline M9 & & & .82 \\
\hline M10 & & & .74 \\
\hline Cronbach Alpha & .79 & .71 & .53 \\
\hline Initial Eigenvalues & 2.78 & 1.98 & 1.72 \\
\hline Total Variance Explained & 27.76 & 19.78 & 17.22 \\
\hline
\end{tabular}

As seen in Table 1 factor analysis findings and factor loadings calculated displays that first subscale on Anxiety has 5 items with factor loadings varying between .67 and .78 . Second is the Importance subscale of 3 items; their factor loadings are identified as varying between .66 and .84 . The factor loadings for the last subscale, Computer Anxiety, are .74 and .82. Total variance explained was calculated as $65 \%$; the first factor variance was explained as $27.7 \%$, the second $19.8 \%$ and $17.2 \%$ for the third one.

For reliability concerns, internal validity coefficients of the items in the questionnaire were calculated through Cronbach Alpha analysis. Internal validity coefficient for the Anxiety subscale was found as .79, and .71 for the Importance subscale and lastly, .53 for the Enjoyment subscale. The opinions of 3 experts the teachers of the experimental and the control group and a statistician have been consulted for the content validity of the questionnaire and to check the level of its meaningfulness. Consequently, the items have been found to be proper to be used for this study. Then, it was piloted on a group of 60 students studying at the School of Basic English with the mixed proficiency levels of elementary to preintermediate. 


\section{Anxiety Subscale}

The anxiety dimension of the scale is composed of five items; perceived time extension when computers involved, difficulty of use, feelings of scariness and nervousness, working as less as possible with computers. The higher the scores of the first dimension were, the more the anxiety levels of the learners were. The means of the dimensions were found and compared separately.

Table 2. Descriptive Statistics for the Anxiety Subscale

\begin{tabular}{llccc}
\hline $\begin{array}{l}\text { Anxiety } \\
\text { subscale }\end{array}$ & Groups & M & SD & N \\
\hline Pre-test & Experimental & 2.39 & .79 & 23 \\
& Control & 2.21 & .75 & 24 \\
& Total & 2.29 & .76 & 47 \\
\hline Post-test & Experimental & 2.47 & .82 & 23 \\
& Control & 2.13 & .94 & 24 \\
& Total & 2.29 & .89 & 47 \\
\hline
\end{tabular}

When the values of the post-tests were analyzed as displayed in Table 2, it was observed that the mean values for the experimental group $(X=2.47)$ were higher than those of the control group $(X=2.13)$. Individual analysis for each group illustrates that experimental group average has increased whereas control group average has decreased.

Regardless of pre and post-test, no significant difference was found between the anxiety values of the experimental and the control group $[\mathrm{F}=1.29, \mathrm{p}>.05]$. The comparison of pre and post-test results did not show a significant difference $[\mathrm{F}=.000, \mathrm{p}>$.05]. It might also be stated that the common effect of test and group variables on anxiety is not meaningful $[\mathrm{F}=.82, \mathrm{p}>.05]$. It is possible to conclude that anxiety values of the control and the experimental group have not altered according to the test variable.

\section{Importance Subscale}

Importance has been identified in three items; working harder if computers are involved, enjoying computers and its effect on motivation to go to school. Information about the importance subscale is displayed in descriptive statistics including the number of participants, mean values and standard deviation data.

Table 3. Descriptive Statistics for the Importance Subscale

\begin{tabular}{llcll}
\hline $\begin{array}{l}\text { Importance } \\
\text { Subscale }\end{array}$ & Groups & $\mathrm{N}$ & $\mathrm{M}$ & \\
\hline Pretest & Experimental & 23 & 3.12 & .86 \\
& Control & 24 & 2.92 & .95 \\
& Total & 47 & 3.01 & .91 \\
\hline Post-test & Experimental & 23 & 2.99 & .90 \\
& Control & 24 & 3.26 & .83 \\
& Total & 47 & 3.13 & .87 \\
\hline
\end{tabular}


Table 3 shows that the post-test mean values for the experimental group is 2.99 and for the control group 3.26 that might reveal the importance attached to the use of computers in the participants' education life. Surprisingly, the level of importance given by the experimental group decreased; whereas, that of the control group increased by the end of the project.

For the ANOVA results showing the significance of the differences between two independent groups (Büyüköztürk, 2006) no difference was observed between the pre and post test values on the importance factor. $[\mathrm{F}=.03, \mathrm{p}>.05]$. The comparative results of pre and post-test values were not significant [F=.71, $\mathrm{p}>.05]$. Moreover, the common measurement effect was not significant either. It is seen that there has been a dramatic increase in the control group for the importance given to computers; however, there is a slight decrease in the experimental group that has worked with computers throughout the semester.

\section{Enjoyment subscale}

Enjoyment subscale has two items; enjoying computers and feeling tired of using them. The mean values for the experimental group were 4.3 and 3.87 for the control group at the beginning of the study. The levels changed dramatically; it has decreased to 3.86 for the experimental group and increased to 4.35 for the control group.

Table 4. Descriptive Statistics for the Enjoyment Subscale

\begin{tabular}{llllr}
\hline $\begin{array}{l}\text { Enjoyment } \\
\text { Subscale }\end{array}$ & Groups & N & M & SD \\
\hline Pretest & Experimental & 23 & 4.30 & .63 \\
& Control & 24 & 3.87 & .85 \\
& Total & 47 & 4.08 & .77 \\
\hline Posttest & Experimental & 23 & 3.86 & .99 \\
& Control & 24 & 4.35 & .60 \\
& Total & 47 & 4.12 & .84 \\
\hline
\end{tabular}

There is no significant difference between enjoyment values of the experimental and control group $[\mathrm{F}=.02, \mathrm{p}>.05]$ as well as the pre and post-test scores $[F=.05, p>.05]$. Nevertheless, common effect of the group and test variables on the enjoyment values of the students is found significant $[\mathrm{F}=21.13, \mathrm{p}<.01]$. In other words, arithmetical averages of both groups signify that experimental group enjoyment values decreased; those of the control group increased.

To briefly restate the Computer Attitude Questionnaire, for the subscales the following can be stated: E-portfolio group became more anxious in computer use after the treatment compared to their previous levels of anxiety. Importance and enjoyment level values of the e-portfolio group decreased at the end of the treatment. Importance and enjoyment level values of the portfolio group increased and this group was found less anxious at the end of the project. 


\section{Motivated Strategies for Learning Questionnaire (MSLQ)}

To get the reliability coefficients, the questionnaire was first piloted on 60 students so was the Computer Attitude Questionnaire. Fifteen items of 31-item questionnaire were omitted after the analyses of the pilot study that were found below .30 item-total correlations. In sum, the questionnaire used in this study had 16 items and their item-total correlations varied between .35 and .75. Alpha coefficient is found as .90 . The revised and finalized motivation scale has only one dimension with a 7-Likert type scale. The motivation levels of the learners have been examined through t-tests; the means of the both groups were compared and their level of motivation was compared based on the available information. It is seen that experimental group has been slightly more motivated than the control group.

Table 5. T-test Results on Learner Motivation Levels

\begin{tabular}{lcccccc}
\hline Groups & $\mathrm{N}$ & Mean & $\mathrm{SD}$ & $\mathrm{t}$ & $\mathrm{df}$ & $\mathrm{p}$ \\
\hline Experimental & 23 & 5.31 & .68 & .813 & 46 & .42 \\
Control & 24 & 5.11 & .96 & & & \\
\hline
\end{tabular}

Table 5 shows that there was not a significant difference between the levels of motivation of two groups before the treatment $[\mathrm{t}=.813, \mathrm{p}>.05]$. Thus, it elaborates that experimental and control group did not differ from each other in terms of their motivation level initial stages of the study.

\section{Pre and Post Test to Assess Writing Skills}

For the performance assessment of the four tasks, a 4-point Likert type scale rubric was adapted from Brown (2001). The paragraphs have been evaluated by two external raters using the same rubric. All assessment scores have been calculated and their mean values were found. Pearson-product moment correlation coefficients were calculated to find the inter-rater grading correlations and thereby the inter-rater reliability in which degree of linear relationship between two variables was examined.

For the posttest results the correlation coefficients are found to be at the level of $.71(\mathrm{p}<.01)$ that signifies a meaningful positive correlation; therefore, the scores by the two raters were summed separately, their mean average was calculated so were the post-test score of the learners. The same procedure has been applied to the pre-test results and the correlation coefficient was identified at the level of .68 $(\mathrm{p}<.01)$ that is meaningful in the positive direction.

Each task in the test needed to be analyzed considering the distinguishing features of the tasks where degree of easiness/difficulty distinguishing the successful learners from unsuccessful ones can be determined. The statistical analysis was conducted using the t-test; first, by forming the lower and upper bounds of the grades followed by calculating and comparing the group means. Distinguishing parameters in Task 1 of the Writing achievement test were found to be significant 
where $\mathrm{t}: 4.53$ and $\mathrm{p}<.01$. For the second Task in the test, the value of the t-test was $\mathrm{t}$ : 3.9 and $\mathrm{p}<.01$ with a significant distinguishing feature. The same analysis with a similar meaningful output for the Task 3 shows t: 4.55 and $p<.01$. For the final task, the analysis produced results as $\mathrm{t}: 4.21$ and $\mathrm{p}<.01$ where significant features of distinguishing can be observed.

After the pilot study, the fifth task which was originally in the test was excluded as it was not a task based writing assignment with a focus on cause-effect relationship where just the 4 topics are given to write a paragraph. Sixty pilot participants filled out the motivation, computer literacy and attitude scales; whereas, for the Writing achievement test only the volunteers were asked to participate as it required willingness, time and effort. Twenty four students completed the tasks; thus, wrote five paragraphs.

The content validity was preserved consulting the two experts of English language teachers who also participated in the development and adaptation of the rubric. Teachers of the control and the experimental group and two more teachers were eager to help and contributed to the study reflecting their opinions and experience based on the curriculum of the school, characteristics and proficiency levels of the learners and the writing skills component.

Table 6. Mean Averages of the Experimental and the Control Group Test Scores

\begin{tabular}{llrcc} 
Tests & Groups & M & SD & N \\
\hline Pre & Experimental & 69.57 & 5.23 & 23 \\
& Control & 64.2 & 7.97 & 24 \\
& Total & 66.77 & 7.25 & 47 \\
\hline Post & Experimental & 76.26 & 6.05 & 23 \\
& Control & 67.32 & 6.49 & 24 \\
& Total & 71.60 & 7.68 & 47 \\
\hline
\end{tabular}

Pretest score means of the experimental group were 69.57 and 64.2 for the control group. Post test results revealed that the experimental group had a mean average of 76.26 which is higher than that of the control group (67.32). It is seen that the experimental group outperformed in the post test that could be interpreted as the positive influence of the e-portfolio process. 
Table 7: Two-factor ANOVA Results with Repeated Measures on One-factor for the Experimental and the Control Group Pre-Post Test Scores

\begin{tabular}{lcrrrr}
\hline Source & um of Squares & df & $\begin{array}{c}\text { Mean } \\
\text { Square }\end{array}$ & F & Sig. \\
\hline Between Subjects & 4444.62 & 47 & & & \\
$\quad$ Groups & 1225.85 & 1 & 1225.85 & 17.52 & .000 \\
$\quad$ Experimental /Control) & & & & & \\
$\quad$ Error & 3218.77 & 46 & 69.97 & & \\
Within subjects & 1380.41 & 48 & & & \\
$\quad$ Measurement & 577.08 & 1 & 577.08 & 36.53 & .000 \\
$\quad$ Pre /Posttest) & & & & & \\
$\quad$ Group*Measurement & $\mathbf{7 6 . 5 8}$ & $\mathbf{1}$ & $\mathbf{7 6 . 5 8}$ & $\mathbf{4 . 8 5}$ & $\mathbf{. 0 3}$ \\
$\quad$ Error & 726.75 & 46 & 15.8 & & \\
Total & 5825.04 & 95 & & & \\
\hline
\end{tabular}

Total scores of experimental and control group were observed to be significantly different regardless of any differentiation in measurement $[\mathrm{F}=17.52$, $\mathrm{p}<.01]$. On the other hand, when pretest and posttest overall scores were checked, there seemed to be an increase in the positive direction in favor of the posttest scores $[\mathrm{F}=36.53, \mathrm{p}<.01]$. In addition, to identify the significance of the research design (eportfolio implementation) common effect of the group and measurement variables were investigated and this common interaction effect was found meaningful $[\mathrm{F}=4.85, \mathrm{p}<.05]$. Therefore, it might be concluded that scores of the experimental group prior to treatment significantly increased more than those in the control group.

\section{Analysis of Data Collection Environment: Dokeos}

The data collection environment was regularly checked while the progress of students and the feedback process were observed at Dokeos. Peer reviews as well as any kind of addition or deletion can be traced easily as the names of the reviewers were visible to all. The tasks were evaluated according to a checklist used both by the classmates and the undergraduate students at the English Language Teaching program each of them matched by the researcher as the responsible peer reviewer. The checklist with 15 statements can be classified as information on title (statement 1 and 2), topic sentence (statement 3 and 4), discourse (statement 5, 6, 9), content (statement 7 and 8), syntax and vocabulary (statement 10 and 11), mechanics (statement 12, 13 and 14). This peer review checklist with its quantitative data was easy to analyze, visualize and see the errors. Figure 2 displays how the names of contributors are listed. 


\begin{tabular}{|c|c|c|c|c|}
\hline $\begin{array}{l}\text { Free Campus - Dokeos } \\
\text { School of Easic English }\end{array}$ & & & & portfolio Derya Eric \\
\hline Campus Homepage My courses Myrofile My agenda & Reporting & & & Logout \\
\hline Eportfolio > Student publications & & & & \\
\hline 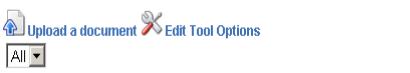 & $1-90 / 90$ & & & $1 / 1$ \\
\hline Title。 & Description & Authors & Date & Modify \\
\hline 473b7c163f878Bahar_KAHVECI_S_portfolio.doc & - & Bahar Kahveci & $\begin{array}{l}\text { 2007-11-15 } \\
15: 21: 44\end{array}$ & 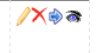 \\
\hline 47336d8a60dabAlparslan.doc & peer review & seyma elik & $\begin{array}{l}2007-11-13 \\
15: 52: 24\end{array}$ & $x \rightarrow 2$ \\
\hline 47337af15e698llknur_KOSTEK.doc & peer checked & Aysun Ören & $\begin{array}{l}\text { 2007-11-12 } \\
\text { 14:11:19 }\end{array}$ & $x \rightarrow \infty$ \\
\hline 47337af15e698llknur_KOSTEK.doc & peer review & hatice özcan & $\begin{array}{l}2007-11-13 \\
16: 08: 16\end{array}$ & $x \rightarrow \infty$ \\
\hline 473850775f43847337af15e698|lknur_KOSTEK.doc & peer review & hatice özcan & $\begin{array}{l}2007-11-13 \\
16: 06: 36\end{array}$ & 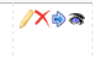 \\
\hline 47337917a536aErkan_PEHLIVAN.doc & peer checked & melike islek & $\begin{array}{l}2007-11-11 \\
13: 56: 02\end{array}$ & $x \rightarrow \infty$ \\
\hline Alkan ULUTAS.doc & Alkan's portfolio & Derya Erice & $2007-11-08$ & $x \rightarrow a$ \\
\hline
\end{tabular}

Figure 2. The Interface of Peer Review

Dokeos also enables its users to see the progress, how much time they have spent in the system and when they last accessed their files. The researcher introduced and demonstrated the checklist by checking a sample text with the learners in class. Though, one of the main problems encountered was the variety in the feedback received. Even when the same entry was analyzed by two different reviewers using the same checklist, the evaluation seemed to differ. For example, one reviewer noted to have four grammatical mistakes whereas for the other one the number of mistakes was more than four.

Randomly selected four students from the e-portfolio group were interviewed for 10 minutes. All in all, students were not as reflective as expected about the use of portfolio. They expressed their overall satisfaction about the system and how it worked. All of the students stated that they liked the idea of working on a file online without the stress of carrying it. On the other hand, they considered the project as an extra burden added to the heavy course requirements. Two of the students interviewed reported that they reviewed the checklist before they start writing. To them, one of the main challenges was lack of computers with the Internet availability; two of the girls stated that they were writing down the paragraphs on pieces of paper and then typing them to a word processing program in an Internet café which required double work and energy. However, they stated that they could observe the improvement in their typing and computer use skills.

\section{Discussion of the Findings}

E-portfolio use has at all times found supporters comparing paper and electronic portfolios: Kuriloff (2005), using the Blackboard online classroom 
system, informed students about course objectives, requirements and assessment criteria while giving opportunities for student collaboration and peer review in a constructive learning environment. The study resulted in positive outcomes favoring the technology integration. Similarly, Dokeos in this study functions like Assignments, Documents, Course Description enabling its users to work in a user friendly atmosphere under the control of both students and the teacher(s). The findings of this study is in line with the research conducted as early as 1996 by Warschauer comparing face to face and online discussions and detected the positive influence of computers on writing skills with future predictions of technology integration in many levels of language education. Furthermore, Woodward and Nanlohy (2004) argued that digital portfolio presents a better organized learning process reflection supplemented by multiple data source with visual and text combination; multimedia and hypermedia. Lastly, Gathercoal, Love, Bryde and McKean (2002) see electronic portfolios more handy that students can access, control and edit the content with no difficulty at all regardless of time and space dependency. It is important that it enables the faculty, instructors, even the parents to follow the learning path of the learners that could also be predicted as an implementation for the Turkish context in a few years of time ahead once portfolios started to have been used in state schools.

In general, the differences between the control and experimental group could be attributed to influences of many factors like personality traits, computer competencies, the time when the users first met computers (Gürcan-Namlu \&Ceyhan, 2003), amount of time spent with computers (Tekinarslan, 2007), computer availability (Sanalan \& Altun, 2002), affective factors (Dunkel, 1991; Reed, 1990; Stansberry \& Kymes, 2007) and motivation (Woodward \& Nanlohy, 2004). The variation of influences was challenging for the research; in this study factors of age, gender and demographic background were not taken into consideration focusing mainly on motivation and attitude. It could be argued that the students' previous experience in computer use and the feeling of ownership are among the leading factors affecting the success in integrating technology.

When the anxiety levels of groups are compared in the pre and post test; the findings revealed that paper based portfolio group became less anxious whereas eportfolio group got more anxious than they had been before. Anxiety levels of the computer users have been recently studied (Gürcan-Namlu \& Ceyhan, 2003; Tekinarslan, 2007) in the national context pointing out the considerable anxiety levels of Turkish students about computers. The findings of this study about anxiety in the MSLQ supports the literature; the degree of anxiety learners feel might be affected by numerous factors such as individual, personal or social that are hard to identify. Here, 'electronic' as a distinguishing medium was taken as the sole factor to be examined; therefore deserves particular attention and helps to interpret the results about technology integration process.

However, the study by Reed (1990) does not support the findings of the current study; Reed examined the effect of computer and writing instruction on prospective teachers' attitude toward computers in writing instruction and reached decreased levels of computer anxiety after the 11-week of implementation. As an explanation 
the study by Gürcan-Namlu and Ceyhan (2003) could contribute to the findings of the current study in that anxiety levels are explained in relation to the demographic features, perceived character properties and experience with computers; if these factors were examined there could have been clearer and more definite results about the reasons and fluctuations in the anxiety levels. Furthermore, Tekinarslan (2007) mentioned relatively high degrees of anxiety among Turkish students considering the context in Turkey and anxiety stemming from lack of computer experience that could also be a factor in this study. While Aşkar and Umay, (2001) linked the challenges to computer experience, frequency of use and conditions of computer accessibility that might help to understand the general context.

The importance and enjoyment levels of students decreased in the e-portfolio group whereas the levels increased in the paper based portfolio group. The statements of CAQ showed that e-portfolio group students did not enjoy the computers as much as they did at the beginning of the project; likewise the level of importance attached to computers decreased. Nevertheless, an increase was observed in the computer anxiety levels. There might be several reasons to explain these findings; paper based group probably used computers for personal purposes mostly like spending their spare time, for communication, fun (playing games, chatting etc.), Googling and for supplementary support for their courses. On the other hand, in addition to these purposes the e-portfolio group was made to log into a system and write their paragraphs which were not very motivating at the beginning due to mainly the inexperience. They have stated that they do not enjoy as much as they did before and they got tired of computers. One and only reason for this result cannot simply be the e-portfolio environment and its functions; some other independent and dependent factors need to be considered like computer as well as Internet availability and experience. It should be kept in mind that these newcomers to the university had trouble finding computer facilities and accessing them whenever they wanted to. The importance factor is more related to the integration of technology in the classes like working harder if computers are involved in the courses and its effect on attending the classes. All in all, the e-portfolio group seemed not to be very motivated when computers were used for educational purposes as a must. What they feel dominantly was nervousness and they were likely to spend as little time as possible on the computers for the courses. Two of the reasons were stated as difficulty in computer use and figuring out its functions and lastly, extra time required to complete a task online.

Finally, Lohr, Ross and Morrison (1996) analyzed the effectiveness of hypertext over an 8 -week implementation of story evaluation written in a hypertext story writing environment and positive outcomes were stated. Teachers are recommended to start the integration with a word processor, to have more control and flexibility over the computers and how it will be used. In an another study, van Waes (2004) experienced spending extra time on word processor in the first draft and less on finalizing a text, pursued a more fragmentary writing process, tended to revise more extensively at the beginning of the writing process viewed digital tools as great aid to writing. Dokeos offered working on a word processing file with which even the most novice students were familiar. Students were relieved when 
they were instructed that they would write their paragraphs on a word processing file which did not require any further explanation. The findings help better see how eportfolio could be integrated and benefited in varying degrees of motivation and attitude factors for different contexts.

\section{CONCLUSIONS}

E-portfolio can be a powerful tool to promote language learning in particular to improve writing skills: Research comparing the paper and web based portfolios attain a general conclusion supporting e-portfolio pointing out its advantages of easiness to carry, share and save; instant access; immediate feedback; reader and reviewer variety and so forth. It can be concluded that it has been a challenge to motivate students about writing that was also observed in writing in an online environment.

This study is significant in that it partially filled the gap in the literature about the e-portfolio implementation in Turkey with a focus on second language writing skills. The literature reviewed had three dimensions; assessment, educational use of technology and second language writing skills that might be of guide to other researchers. First, teachers and students participated in this study experienced how technology could be used for educational purposes. Secondly, formative assessment was introduced through process writing with the student involvement in decision making and feedback stages. Students enjoyed their role as an assessor and as an active constructor contrary to their traditional passive roles.

Teachers might benefit from the study seeing the applicability of e-portfolio in language classes. Foreign language teachers can use more standardized forms of digital portfolio or create authentic ones according to the course objectives. Administrators might benefit the study that clearly shows how cost-effective and time-saving e-portfolios can be in addition to its potential effect on student achievement. When administrators are introduced e-portfolios, they might change their attitude and perspective in a positive way if were otherwise. E-portfolios are widely used at the higher education level allowing the entire faculty and students have their own portfolios in the shared system. They can be integrated in all levels of education including even the preschools. On the other hand, students might enjoy their roles that shifted from passive to active learners while working dynamically in an online environment keeping track of their own progress as well as their classmates'.

For further research, it is recommended that e-portfolio be practiced in different online environments comparing the features, with learners at different proficiency levels and in other levels of education. E-portfolio can be integrated into foreign language classrooms to assess a variety of skills documenting progress over time. It is an effective tool to assess in particular the writing skills of autonomous foreign language learners in that they can document and save their products in a safe, secure and fun way. 


\section{REFERENCES}

Al Kahtani, S. (1999). Electronic portfolios in ESL writing: An alternative approach. Computer Assisted Language Learning, 12 (3), 261-268.

Aşkar, P., \& Umay, A. (2001). İlköğretim Matematik Öğretmenliği öğrencilerinin bilgisayarla ilgili öz-yeterlik algısı. Hacettepe Üniversitesi Eğitim Fakültesi Dergisi, 21, 1-8.

Avraamidou, L., \& Zembal-Saul, C. (2002). Making the case for the use of web-based portfolios in support of learning to teach. The Journal of Interactive Online Learning, 1 (2).

Aydin, S. (2006). The effect of computers on the test and inter-rater reliability of writing tests of ESL learners. The Turkish Online Journal of Educational Technology, 5 (1).

Brown, D. H. (2001). Teaching by Principles: An Interactive Approach to Language Pedagogy. NY: Pearson Education.

Bryant, S. L., \& Timmins, A.A. (2002). Portfolio Assessment: Instructional Guide: Second Edition. Hong Kong: Hong Kong Institute of Education. (Available: http://libdr1.ied.edu.hk/pubdata/img00/arch00/link/archive/1/instarh/1921_image.pd f)

Büyüköztürk, Ş. (2006). Veri Analizi El Kitabı. Ankara: Pegem Yayıncılık.

Büyüköztürk, Ş., Akgün, O. E., Özkahveci, O., \& Demirel, F. (2004). The validity and reliability study of the Turkish version of the Motivated Strategies for Learning Questionnaire. Kuram ve Uygulamada Eğitim Bilimleri/ Educational Sciences: Theory \& Practice, 4 (2), 231-239.

Chang, Y., Wu, C., \& Ku, H. (2004). The introduction of electronic portfolios to teach and assess English as a foreign language in Taiwan. TechTrends, 49 (1).

Dunkel, P. (1991). The effectiveness research on computer-assisted instruction and computer assisted language learning. In P. Dunkel (Ed.), Computer Assisted Language Learning and Testing: Research Issues and Practice. USA: Newbury House.

Gathercoal, P., Love, D., Bryde, B., \& McKean, G. (2002). On Implementing Web-based electronic portfolios. Educause Quarterly, 7 (2).

Gülbahar, Y., \& Köse, F. (2006). Öğretmen Adaylarının Değerlendirme için Elektronik Portfolyo Kullanımına İlişkin Görüşleri. Ankara Üniversitesi Eğitim Bilimleri Fakültesi Dergisi, 39(2), 75-93.

Gürcan-Namlu, A., \& Ceyhan, E. (2003). Bilgisayar Kaygıs1: Ögretmen adayları üzerinde çok yönlü bir inceleme. Kuram ve Uygulamada Eğitim Bilimleri/ Educational Sciences: Theory \& Practice, 2, 401-432.

Jenkins, C. B. (1996). Inside the Writing Portfolio: What we need to know to assess children's writing. $\mathrm{NH}$ : Heinemann.

Knezek, G., Christensen, R., Gilmore, E., Kim, H., Morales, C., Voogt, J., \& Moonen, B. (1999)

Teacher \& Student Attitudes toward Information Technology in Four Nations. Panel presented at Society of Information Technology \& Teacher Education (SITE)'s 10th International Conference, San Antonio, TX, March 2, 1999. 
Kuriloff, P. 2005. Breaking the Barriers of Time and Space: More Effective Teaching Using e-Pedagogy. Innovate, 2 (1). http://www.innovateonline.info/index.php?view=article\&id=64

Li, Y. (2000). Linguistic Characteristics of ESL Writing in Task-based E-mail Activities. System, 28 (2), 229-245.

Lohr, L., Ross, S. M., \& Morrison, G. R. (1996). Using a Hypertext Environment for Teaching Process Writing: An Evaluation Study of Three Student Groups. Proceedings of Selected Research and Development Presentations at the 1996 National Convention of the Association for Educational Communications and Technology.

O’Malley, J. M., \& Valdez-Pierce, L. (1996). Authentic Assessment for English Language Learners. USA: Addison-Wesley Publishing Company.

Pintrich, P. R., \& De Groot, E.V. (1990). Motivational and self-regulated learning components of classroom academic performance. Journal of Educational Psychology, 82, 33-40.

Reed, M. (1990). The Effect of Computer-and-Writing Instruction on Prospective English Teachers' Attitudes toward and Perceived Uses of Computers in Writing Instruction. Journal of Research on Computing in Education, 23 (1), 3-27.

Sanalan, A., \&Altun, A. (2002). Bir veri tabanı uygulaması olarak elektronik portfolyo kullanımı. Erzincan Egitim Fakültesi Dergisi, 4 (1), 10-20.

Shores, E. F., \& Grace, C. (1998). The Portfolio Book: A Step-by-Step Guide for Teachers. USA: Gryphon House, Inc.

Soloway, E., Norris, C., Knezek, G., Becker, H., Riel, M., \& Means, B. (1999). The Relationship of Teachers and Technology: Survey Findings and Reflections. Panel presented at Society of Information Technology \& Teacher Education (SITE)'s 10th International Conference, San Antonio, TX, March 3, 1999.

Stansberry, S. L., \& Kymes, A. D. (2007). Transformative Learning through "Teaching with Technology" Electronic Portfolios. Journal of Adolescent \& Adult Literacy, 50 (6), 488-496.

Tamar, L., \& W. Rivka (2006). Teachers' Beliefs and Practices in TechnologyBased Classrooms: A Developmental View. Journal of Research on Technology in Education, (39)2, 157- 181.

Tekinarslan, E. (2007). Computer anxiety: A cross-cultural comparative study of Dutch and Turkish university students. Computers in Human Behavior, doi: 10.1016/j.chb.2007.05.011

Tezci, E., \& Dikici, A. (2006). The effects of digital portfolio assessment process on students' writing and drawing performances. The Turkish Online Journal of Educational Technology, 5 (2).

Tierney, R.J., Carter, M.A., \& Desai, L.E. (1991). Portfolio Assessment in the Reading-writing Classroom. Norwood, MA: Christopher Gordon Publishers.

Van Waes, L. (2004). Collaborative Writing in a Digital Environmental. Information Design Journal \& Document Design, 12(1), 73-80.

White, R. (1987). Approaches to writing. In M. H. Long \& J. C. Richards (Eds.). Methodology in TESOL Book of Readings. USA: Heinle \& Heinle Publishers. 
Warschauer, M. (2007). Technology and writing. In C. Davison \& J. Cummins (Eds.), The International Handbook of English Language Teaching (pp. 907-912). Norwell, MA: Springer.

Warschauer, M., L. Turbee \& B. Roberts (1996). Computer Learning Networks and Student Empowerment. System 24 (1), 1-14.

Williams, M. \& Burden, R.L. (1997). Psychology for Language Teachers. UK: Cambridge University Press.

Woodward, H. \& Nanlohy, P. (2004). Digital portfolio: Fact or fashion? Assessment \& Evaluation in Higher Education, 29 (2), 227-238. 